\title{
10. MIOCENE CALCAREOUS NANNOFOSSIL BIOSTRATIGRAPHY OF DEEP SEA DRILLING PROJECT HOLE 521A (SOUTHEAST ATLANTIC)1
}

\author{
Anna K. von Salis, Instituut voor Aardwetenschappen, Vrije Universiteit, De Boelelaan 1086, \\ Amsterdam, The Netherlands
}

\begin{abstract}
The middle/lower upper Miocene coccolith biostratigraphy of Cores 12 and 13 in Hole 521A is given, and the reasons for the absence of Helicosphaera and Sphenolithus in most of the interval studied are speculated upon.

The lowest occurrence of Catinaster coalitus, which defines the base of NN8 in Magnetostratigraphic Chron C-5, confirms the observations made at Site 519 and at Hole 521 and suggests that the numerical age of NN8 is younger than previously supposed (see Hsü et al., this vol.).
\end{abstract}

\section{BIOSTRATIGRAPHY}

Smear slides of calcareous nannofossils of Cores 12 and 13 of DSDP Hole 521A from the Mid-Atlantic Ridge in the South Atlantic were studied in detail to date the samples used for the paleomagnetic studies performed by Heller et al. (this vol.) and summarized by Hsü et al. (Site 521 chapter, this vol.). The results are presented in Table 1; the age interpretation in the figure was based on the coccolith zonation of Martini (1971). The lowermost part of Core 13 can be assigned to the Sphenolithus heteromorphus zone (NN5) because of the presence of the name-giving species and the absence of Helicosphaera ampliaperta. Actually the absence of $H$. ampliaperta in an assemblage that lacks helicosphaerids altogether is likely to be due to paleoenvironmental reasons rather than to the extinction of the species and therefore should not be used for the zonal assignment at Site 521. Nevertheless, since $S$. heteromorphus extends down to the lowermost sample acquired (Sample 521$21, \mathrm{CC}$ ), and since this sample also contains $H$. carteri and $H$. euphratis but not $H$. ampliaperta (Percival, this vol.), the assignment to NN5 of the uppermost samples that contain $S$. heteromorphus seems justified. $S$. heteromorphus is quite common in Samples 521A-13-3, $108 \mathrm{~cm}$ and $521 \mathrm{~A}-13-3,46 \mathrm{~cm}$, whereas only very rare, poorly preserved specimens were found in Samples $521 \mathrm{~A}-13-2,144 \mathrm{~cm}$ and $521 \mathrm{~A}-13-3,104 \mathrm{~cm}$. From Sample $521 \mathrm{~A}-13-2,87 \mathrm{~cm}$ through $521 \mathrm{~A}-12, \mathrm{CC}(3 \mathrm{~cm})$ the sequence is assigned to NN6/NN7, a combined Discoaster exilis/D. kugleri zone, since no typical specimens of $D$. kugleri were found. Some specimens similar to $D$. $k$ ugleri occur sporadically from the base through the top of the interval. Within this interval the change of dominance within the family of the Prinsiaceae from Cyclicargolithus floridanus to Reticulofenestra pseudoumbilica (or a predecessor of $\boldsymbol{R}$. pseudoumbilica, depending

\footnotetext{
${ }^{1}$ Hsï, K. J., LaBrecque, J. L., et al., Init. Repts. DSDP, 73: Washington (U.S. Govt. Printing Office).
}

on the species concept used) can be observed between Samples 521A-13-1, $86 \mathrm{~cm}$ and 521A-13-1, $81 \mathrm{~cm}$, only about $100 \mathrm{~cm}$ below the level of disappearance of $C$. floridanus. As one proceeds upsection, Discoaster variabilis and $D$. challengeri increase, and $D$. exilis decreases, in abundance.

The lowermost Catinaster coalitus appears in Sample $521 \mathrm{~A}-12-3,17 \mathrm{~cm}$, where the species is very rare but is taken to mark the base of NN8, the $C$. coalitus zone. Heller et al. (this vol.) could show that this datum falls within Magnetostratigraphic Chron C-5, suggesting a numerical age considerably younger than previously assumed (Hsü et al., this vol.). The abundance of C. coalitus increases, and it is more common than the other species of the genus, $C$. calyculus, up to Sample 521A-12-2, $15 \mathrm{~cm}$. Above this level C. calyculus becomes more common, and its uppermost occurrence is in Sample 521A$12-1,90 \mathrm{~cm}$, where it is very rare. The two species are usually found together in the upper part of NN8 and in NN9, and C. calyculus reaches halfway up into NN10, the $D$. calcaris zone. For a better subdivision of the interval according to the Martini zonation, the presence of $D$. hamatus, which defines Zone NN9, would be necessary. Only one specimen of $D$. hamatus was found, in Sample 521A-12-2, $15 \mathrm{~cm}$, and the assignment of this sample to NN9 thus is not beyond doubt.

Dissolution is evident in most samples and went so far as to leave Sample 521A-13-1, $48 \mathrm{~cm}$ barren of calcareous nannofossils. While some discoasters show heavy overgrowth, others seem little affected by either dissolution or overgrowth. It should be interesting to establish a detailed curve of the $\mathrm{CaCO}_{3}$ content for the middle Miocene. Comparisons with dissolution data in other South and North Atlantic sites could be established on the basis of the following coccolith events: the HO (highest occurrence) of $S$. heteromorphus, the dominance change from Cyclicargolithus floridanus to $R$. pseudoumbilica, the LO (lowest occurrence) of Catinaster coalitus, the LO of C. calyculus, the change in dominance from $C$. coalitus to $C$. calyculus, the HO of $C$. coalitus, and the $\mathrm{HO}$ of $C$. calyculus. 
Table 1. Distribution of calcareous nannofossils in Cores 12 and 13 of Hole 521A. ${ }^{\mathrm{a}}$ All samples were dated as middle Miocene.

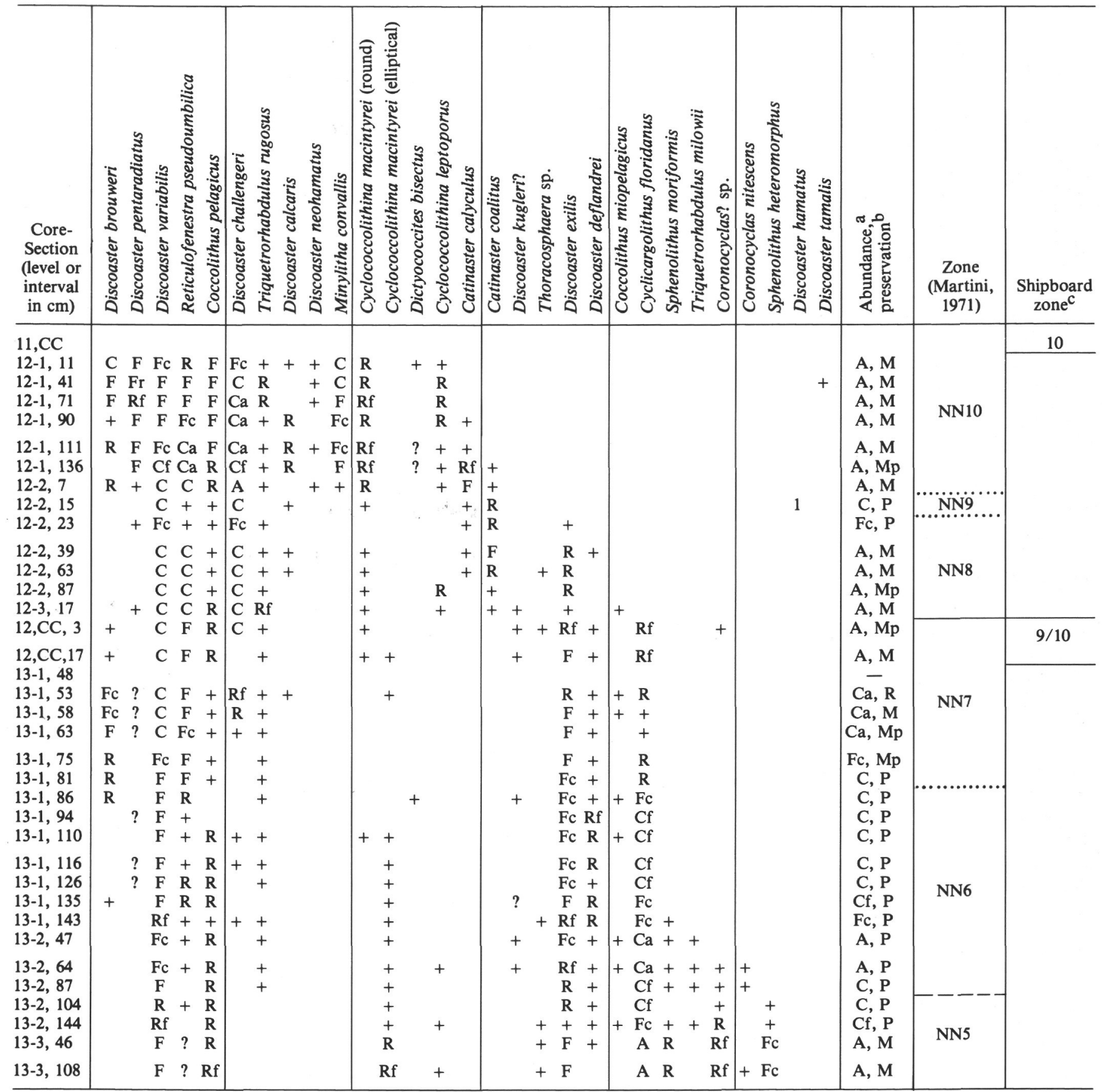

Note: Lower case letters denote tendency toward condition noted. Nannofossil boundaries denoted by solid, dashed, and dotted lines are progressively less certain.

${ }_{\mathrm{b}}^{\mathrm{A}}, \mathrm{a}=$ abundant; $\mathrm{C}, \mathrm{c}=$ common; $\mathrm{F}, \mathrm{f}=$ few; $\mathrm{R}, \mathrm{r}=$ rare; + = present; ? = possibly present.

$\mathrm{b} \mathbf{M}=$ moderate; $\mathrm{P}, \mathrm{p}=$ poor.

c Core catcher samples from Cores $13,14,15$, and 16 were assigned to shipboard zone 5 . Core catcher sample from Core 17 was assigned to shipboard zone 4 .

\section{REMARKS}

It is worth noting that sphenoliths are only present in the lowermost part of the sequence studied. Sphenolithus heteromorphus is reasonably well represented, whereas $S$. moriformis is rare. Very rare specimens of $S$. moriformis persist up to a level about $100 \mathrm{~cm}$ higher than the $\mathrm{HO}$ of the very rare $S$. heteromorphus. The $\mathrm{HO}$ of $S$. heteromorphus is recognized and used for correlations worldwide in the low and midlatitudes and may represent the extinction of the sphenolith lineage $S$. moriformis-S. dissimilis-S. delphix-S. conicus-S. heteromorphus. The disappearance of $S$. moriformis s.a. is puzzling, since this sphenolith is not especially prone to 
dissolution and is known from younger sediments of many areas.

The absence of any species of Helicosphaera is equally remarkable, since the specimens of Helicosphaera are not especially prone to dissolution either, and $H$. carte$r i$, at least, is usually found in the interval studied. Do we have to explain the temporary absence of sphenoliths and/or Helicosphaera by the location of Site 521 on the relatively young Mid-Atlantic Ridge? Did the surfacewater conditions during this time in the central South Atlantic prevent sphenoliths and Helicosphaera from living there? And what allowed Helicosphaera to become abundant later on in the Pliocene and Pleistocene? $H$. carteri appears in live samples and in sediment samples from the Atlantic (McIntyre and Bé, 1967), but its dis- tribution gives no answers as yet. $H$. carteri and related forms are known from the early Miocene and still live today, and their distribution may provide information about paleoenvironments once we understand the reasons for their presence and absence.

\section{REFERENCES}

Martini, E., 1971. Standard Tertiary and Quaternary calcareous nannoplankton zonation. In Farinacci, A. (Ed.), Proc. Second Planktonic Conf.: Rome (E. Tecnoscienza), pp. 739-785.

McIntyre, A., and Bé, A. W. H., 1967. Modern Coccolithophoridae of the Atlantic Ocean-I. Placoliths and Cyrtoliths. Deep Sea Res., 14:561-597.

Date of Initial Receipt: October 4, 1982 